Article

\title{
Fuel-N Evolution during the Pyrolysis of Industrial Biomass Wastes with High Nitrogen Content
}

\author{
Hongfang Chen ${ }^{1, *}$, Yin Wang ${ }^{2}$, Guangwen $X u^{3{ }^{3} *}$ and Kunio Yoshikawa ${ }^{1}$
}

1 Department of Environmental Science and Technology, Tokyo Institute of Technology, G5-8, 4259

Nagatsuta, Midori-ku, Yokohama 226-8502, Japan; E-Mail: yoshikawa.k.aa@m.titech.ac.jp

2 Institute of Urban Environment, Chinese Academy of Sciences, Xiamen 361021, China;

E-Mail: yinwang@iue.ac.cn

3 Institute of Process Engineering, Chinese Academy of Sciences, No. 1 Zhongguancun North Second Street, Beijing 100190, China

* Authors to whom correspondence should be addressed; E-Mails: chen.h.ad@m.titech.ac.jp (H.C.); gwxu@home.ipe.ac.cn (G.X.); Tel.: +81-459-245-507 (H.C.); +86-10-82544886 (G.X.); Fax: +81-459-245-518 (H.C.); +86-10-82544886 (G.X.).

Received: 10 September 2012; in revised form: 14 December 2012 / Accepted: 14 December 2012 / Published: 19 December 2012

\begin{abstract}
In this study, sewage sludge and mycelial waste from antibiotic production were pyrolyzed in a batch scale fixed-bed reactor as examples of two kinds of typical industrial biomass wastes with high nitrogen content. A series of experiments were conducted on the rapid pyrolysis and the slow pyrolysis of these wastes in the temperature range from $500-800{ }^{\circ} \mathrm{C}$ to investigate the Fuel-N transformation behavior among pyrolysis products. The results showed that Fuel-N conversion to Char-N intimately depended on the pyrolysis temperature and the yield of Char-N reduced with the increase of the pyrolysis temperature. Under the same pyrolysis conditions, Tar-N production mainly depended on complex properties of the different biomasses, including volatile matter, nitrogen content and biomass functional groups. $\mathrm{HCN}$ was the predominant $\mathrm{NO}_{\mathrm{x}}$ precursor in the rapid pyrolysis of biomass, whereas in the slow pyrolysis of mycelial waste, more $\mathrm{NH}_{3}$ was produced than $\mathrm{HCN}$ due to the additional $\mathrm{NH}_{3}$ formation through the hydrogenation reaction of Char-N, $\mathrm{HCN}$ and $\mathrm{H}$ radicals. At the same time, some part of the char was analyzed by Fourier Transform infrared spectroscopy (FTIR) to get more information on the nitrogen functionality changes and the tar was also characterized by Gas Chromatography and Mass Spectrometry (GCMS) to identify typical nitrogenous tar compounds. Finally, the whole nitrogen distribution in products was discussed.
\end{abstract}


Keywords: Fuel-N; industrial biomass wastes; pyrolysis; $\mathrm{NO}_{\mathrm{x}}$ precursors; Tar-N; Char-N

\section{Introduction}

At present, with the sustained industrial growth, huge amounts of industrial wastes are produced that cause lots of serious environmental pollution problems. At the same time, due to their high organic matter content, most of them have already been identified as a major source of biomass and accordingly called industrial biomass wastes. Every year in China, the total amount of industrial biomass wastes has been more than 400 million tons. Most of them are produced by pharmaceutical companies, food industries, beverage production and wastewater plants, such as 30 million tons of sewage sludge from wastewater plants and 2 million tons of mycelial waste produced annually from medicine manufacturing.

Those typical industrial biomass wastes have similar properties with high nitrogen and water contents, causing a lot of environmental problems and until now they have no effective way of utilization. In particular the mycelial wastes from antibiotic production are already classified as dangerous solid wastes according to the current regulations in China, so it is urgent to develop some effective technologies to deal with these wastes. In that case, the thermal conversion technologies such as pyrolysis, gasification and combustion have now been developed to alleviate the environmental load and are also aimed to be applied in power generation due to the carbon-neutral nature of biomass resource and comparable heating value to low rank coals. However, during the thermal conversion of biomass, the nitrogen in biomass is released as nitrogen-containing volatiles (volatile-N) including $\mathrm{NO}_{\mathrm{x}}$ precursor gases such as ammonia $\left(\mathrm{NH}_{3}\right)$, hydrogen cyanide $(\mathrm{HCN})$, isocyanic acid $(\mathrm{HNCO})$ and nitrogen oxides $\left(\mathrm{NO}_{\mathrm{x}}\right.$ and $\left.\mathrm{N}_{2} \mathrm{O}\right)$, toxic contaminants like organic nitrogenated compounds and $\mathrm{N}_{2}$. The rest of the nitrogen is left in the char $(\mathrm{Char}-\mathrm{N})$. It is well known that those $\mathrm{NO}_{\mathrm{x}}$ precursors, organic nitrogenated compounds and nitrogen in char may then be emitted as $\mathrm{NO}_{\mathrm{x}} / \mathrm{N}_{2} \mathrm{O}$ which are pollutants causing photochemical smog, acid rain, the greenhouse effect and ozone depletion after being combusted and gasified [1,2]. As a result, the viability of new thermal utilization technologies of industrial biomass wastes in the future [3], to a large extent, will be determined by their $\mathrm{NO}_{\mathrm{x}}$ emissions.

During thermal conversion, although thermal $\mathrm{NO}_{\mathrm{x}}$ and prompt $\mathrm{NO}_{\mathrm{x}}$ also can be formed, the Fuel-N is the major source of NOx emission. In order to effectively minimize the $\mathrm{NO}_{\mathrm{x}}$ emission, more attention should be paid to the Fuel-N behavior during the thermal conversion [4]. Because pyrolysis is regarded as one of the simplest thermal process is not only an important method for bio-oil production but also the primary stage of either combustion or gasification, understanding the behavior of Fuel-N during the pyrolysis process will be significant for the choice of optimum reaction conditions during either combustion or gasification processes in the future.

Up to now, a lot of intensive studies on the formation of NOx precursors (mainly $\mathrm{HCN}$ and $\mathrm{NH}_{3}$ ) and nitrogen evolution during the pyrolysis of coal have been carried out [5-12] and can supply some knowledge about nitrogen behavior during the pyrolysis of biomass by virtue of their certain similarities. However, nitrogen functionalities in biomass are different from those in coal [6]. Nitrogen in coal mainly exists in heteroaromatic ring systems as pyrrolic and pyridinic $\mathrm{N}$, while nitrogen in biomass 
mainly exists as proteins (and amino acids) together with some other forms such as DNA, RNA, alkaloids, porphyrin, and chlorophyll $[13,14]$. Moreover, some biomass fuels produce more NOx than coal on the basis of the heating value [15], especially for those typical industrial biomass wastes with high nitrogen content mentioned above. Owing to the differences of nitrogen amount and nitrogen functionalities between biomass and coal, those results for coal pyrolysis are not completely suitable to illustrate the behavior of nitrogen during the pyrolysis of biomass.

Thus some researchers $[2,6,8,13]$ have been devoting their efforts to investigate the Fuel-N evolution during the pyrolysis of biomass. It is well known that during the pyrolysis of biomass, the main NOx precursors are ammonia $\left(\mathrm{NH}_{3}\right)$ and cyanide $(\mathrm{HCN})$. However, in terms of the conversion of the Fuel-N to $\mathrm{HCN}$ and $\mathrm{NH}_{3}$ during the pyrolysis of biomass, differing results have been obtained. In some studies, a high concentration of $\mathrm{NH}_{3}$ was observed [14,16], whereas in other studies $\mathrm{HCN}$ was found to dominate [2,8], while some works showed that roughly equal amounts of $\mathrm{HCN}$ and $\mathrm{NH}_{3}$ were produced $[17,18]$. The reasons for those differences are that the nitrogen migration characteristics including the Fuel-N conversion to $\mathrm{HCN}$ and $\mathrm{NH}_{3}$ during pyrolysis are affected by diverse conditions such as the biomass fuel type, the reactor structure, the heating rate, the final temperature and the residence time. In addition to that, most of those studies $[2,6,17,18]$ involved biomass with relatively low N-content. The reliability of the results has become a major question as the uncertainties might be significant. Besides those facts, it is well known that during pyrolysis, the Fuel-N is partitioned between the volatiles and char. The volatile nitrogen is released either as volatile nitrogen compounds in the tar phase or as nitrogen-containing gaseous species, including $\mathrm{N}_{2}$, some of which are $\mathrm{NO}_{\mathrm{x}}$ precursors, and can then be oxidized to $\mathrm{NO}_{\mathrm{x}}$ during subsequent combustion. The rest of the Fuel-N is retained in the resultant char. However, the Char-N can form NO directly by a heterogeneous process (and from $\mathrm{HCN}$ ) during combustion. In some studies [13,16,19], although the characteristics of $\mathrm{NO}_{\mathrm{x}}$ precursors $\left(\mathrm{HCN} / \mathrm{NH}_{3}\right)$ produced from certain biomass with relatively high nitrogen content such as thermally thick samples (3.0-4.0 wt \%, dry ash free basis) and soybean cake (4.45 wt \%) were well investigated, not enough information about other nitrogen-containing products was indicated. In a word, the situation necessarily calls for comprehensive observation of Fuel-N migration and distribution among every part of the nitrogen containing products using typical industrial biomass wastes whose nitrogen content are high enough so that an innovative low $\mathrm{NO}_{\mathrm{x}}$ emission technology can be developed to treat these industrial biomass wastes with high nitrogen content.

This study aims to understand the Fuel-N behavior or characteristics during the pyrolysis of industrial biomass wastes with high nitrogen content and achieve a better quantitative understanding of the separate effects of the temperature, the heating rate and the properties of biomass on pyrolysis reactions so as to develop novel combustion and gasification technologies with low $\mathrm{NO}_{\mathrm{x}}$ emissions. Two kinds of typical industrial biomass wastes with high nitrogen content - sewage sludge from wastewater plants and mycelial waste from antibiotic production-were chosen as biomass fuels and pyrolyzed at different heating rates (rapid/slow pyrolysis) in the temperature range of $500-800{ }^{\circ} \mathrm{C}$. The effects of those conditions on the formation and distribution of various nitrogen-containing products and the relationships among them were investigated and are discussed. Moreover, in order to understand the nitrogen status in the various phases, the characteristics of tar and char were analyzed by Gas Chromatography and Mass Spectrometry (GCMS) and Fourier Transform infrared spectroscopy (FTIR), respectively. 


\section{Experimental Methods}

\subsection{Material}

In this study, two kinds of sewage sludge obtained from wastewater treatment plants and mycelial waste obtained from an antibiotic production company were prepared as typical industrial biomass wastes with high nitrogen content and used as fuels. Those two kinds of typical industrial wastes have peculiar characteristics. Their organic matter is largely due to the presence of dead microorganisms like bacteria or other species, which are responsible for either the removal of the waste organic matter from water or for producing antibiotic medicines. It is well known that microbial constituents mainly consist of nucleic acid, proteins, carbohydrates and lipid [20]. Hence the Fuel-N in sewage sludge and mycelial waste mainly exists in the form of nucleic acids and proteins of dead microorganisms. For sewage sludge, due to the diverse properties of wastewater and various treatment processes, the characteristics are different. Based on above consideration, two different origins of sludgeA and sludgeB, which were produced at a wastewater plant in Beijing, China and a wastewater plant in Inner Mongolia, China, respectively, were chosen as biomass fuels and firstly dried at $105{ }^{\circ} \mathrm{C}$ in an electric oven. Mycelial waste obtained from an antibiotic production company used to compare with sewage sludge was also firstly dried under the same conditions as the sewage sludge. After drying, three samples were crushed and sieved to the same size range of $0.45-0.71 \mathrm{~mm}$ to eliminate the influence of the particle size of samples. The analysis results of the samples are presented in Table 1.

Table 1. Properties of the studied industrial biomass wastes.

\begin{tabular}{|c|c|c|c|}
\hline Samples & Mycelial Waste & SludgeA (Beijing, China) & SludgeB (Inner Mongolia, China) \\
\hline \multicolumn{4}{|c|}{ Proximate analysis (wt \%, dry basis) } \\
\hline Volatile & 29.1 & 44.8 & 37.9 \\
\hline $\mathrm{FC}$ & 10.6 & 13.3 & 10.4 \\
\hline Ash & 60.3 & 41.9 & 51.7 \\
\hline \multicolumn{4}{|c|}{ Ultimate analysis (wt \% dry-ash free basis) } \\
\hline $\mathrm{C}$ & 39.7 & 49.7 & 54.4 \\
\hline $\mathrm{H}$ & 6.1 & 7.0 & 7.1 \\
\hline $\mathrm{S}$ & 3.9 & 1.2 & 1.3 \\
\hline $\mathrm{N}$ & 6.2 & 7.6 & 7.1 \\
\hline $\mathrm{O}^{\mathrm{a}}$ & 44.1 & 34.5 & 30.1 \\
\hline
\end{tabular}

\subsection{Experimental Procedure}

The experimental apparatus is a batch scale facility which mainly consists of a gas supplying system, a pyrolyzer and a sampling system. A schematic diagram is shown in Figure 1.

In order to avoid thermal $\mathrm{NO}_{\mathrm{x}}$ and prompt $\mathrm{NO}_{\mathrm{x}}$ formation caused by $\mathrm{N}_{2}$ in air, high purity argon gas (99.999\%) was used as the carrier gas and the flow rate was controlled at $400 \mathrm{~mL} / \mathrm{min}$. The pyrolyzer made from quartz cylinder was a fixed bed reactor (36 $\mathrm{mm}$ in diameter, $800 \mathrm{~mm}$ in height), which was heated with a vertical furnace. The reactor was composed of a tubular reactor with a sintered quartz porous plate, which was set up near the bottom of the outlet, and a top cover with an injection tube. 
Figure 1. Experimental apparatus.

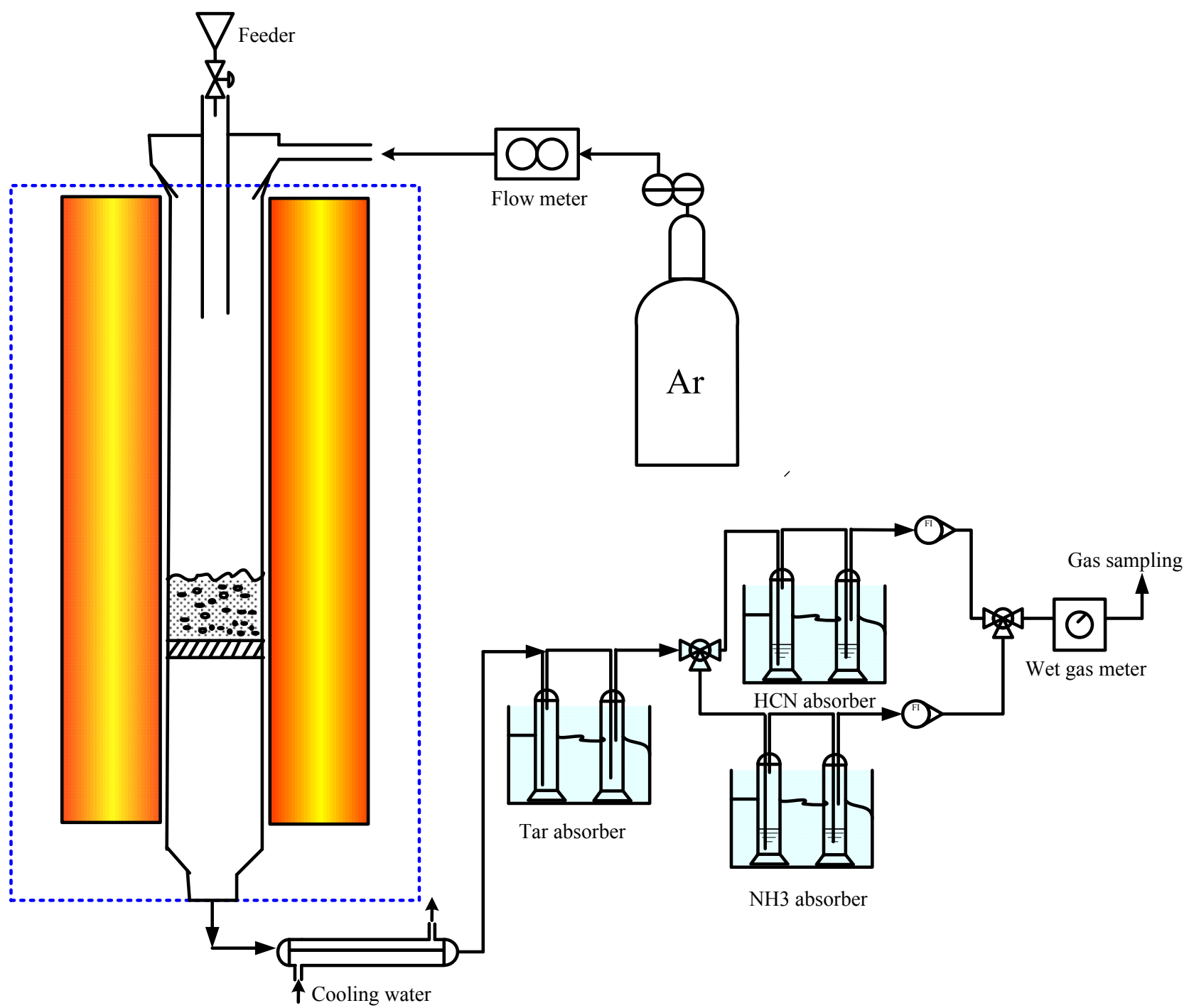

For the slow pyrolysis experiments, the feedstock materials were firstly put into the pyrolyzer and then argon gas was used to purge out air at the flow rate of $600 \mathrm{~mL} / \mathrm{min}$ at least for $0.5 \mathrm{~h}$. At the beginning of experiments, the argon gas was adjusted to $400 \mathrm{~mL} / \mathrm{min}$. Then the temperature of the pyrolyzer was slowly heated up with the heating rate of $10 \mathrm{~K} / \mathrm{min}$ to the final pyrolysis temperature and was held for $0.5 \mathrm{~h}$ to ensure that all reactions were completed. For the rapid pyrolysis experiments, the reactor was firstly heated up to the designated temperature $\left(500-800{ }^{\circ} \mathrm{C}\right)$ and stably kept at the constant temperature while argon gas passed through all the system to purge out air at the flow rate of $600 \mathrm{~mL} / \mathrm{min}$ for at least $0.5 \mathrm{~h}$. Then about $15 \mathrm{~g}$ feedstock materials were supplied into the pyrolyzer from the top injection with a sealed feeding tube. During the drop of biomass with carrier gas, the biomass sample would be better dispersed and instantaneously heated up to rapidly generate pyrolysis products. The total experimental period lasted for $0.5 \mathrm{~h}$ to ensure that all pyrolysis products were completely collected within the same residence time at the final pyrolysis temperature as for the slow pyrolysis.

Producer gases passed through the sampling system and were separately collected. Firstly, tar aerosol was mostly sampled in the water-glycol condenser pipe which was cooled down to $-20{ }^{\circ} \mathrm{C}$ 
using a condenser circulation pump. Following to the condenser, four empty bottles $(250 \mathrm{~mL})$ immersed in the mixture of ice/water were used to ensure that the remaining tar was completely collected in the cold traps. In our previous experiments, in order to completely sample the tar compounds from the producer gas, impinger bottles filled with acetone were used to completely absorb tar. However, parallel experiments with and without acetone were conducted and it was found that although the differences between the tar amount obtained from two methods was small $( \pm 4.0 \%)$, it caused a great effect on $\mathrm{NH}_{3}$ and $\mathrm{HCN}$ (about a 10-fold difference for $\mathrm{NH}_{3}$ concentration and a 5-fold difference for $\mathrm{HCN}$ concentration) due to condensation of some $\mathrm{NH}_{3}$ and $\mathrm{HCN}$ in the acetone solution. Thus, for all the experiments performed in this work, tar was sampled without acetone. After the tar sampling, $\mathrm{NH}_{3}$ and HCN left in the producer gas were sampled in the parallel aqueous bottles [21] due to the high solubility of $\mathrm{HCN}$ and $\mathrm{NH}_{3}$ in the solution [2]. $\mathrm{NH}_{3}$ and $\mathrm{HCN}$ sampling methods were conducted based on the JIS K0099-2004 method for $\mathrm{NH}_{3}$ determination and the JIS K0109-1998 method for HCN determination in flue gas, respectively. Four bottles $(250 \mathrm{~mL})$ containing solutions were divided into two groups and were immersed in a mixture of water/ice bath kept at low temperature to completely absorb the gases. In each group, the second bottle was used to confirm that an efficient absorption had happened in the first one. $\mathrm{NH}_{3}$ as a basic compound was collected in the acidic solution of $5 \mathrm{~g} / \mathrm{L}$ boric acid, whereas, $\mathrm{HCN}$ as an acidic compound was collected in a basic solution of $0.5 \mathrm{M} / \mathrm{L} \mathrm{NaOH}$. The $\mathrm{NH}_{3}$ and $\mathrm{HCN}$ gas sampling bottles were filled with $100 \mathrm{~mL}$ acidic and $100 \mathrm{~mL}$ basic solutions, respectively, and the flow rate of $\mathrm{NH}_{3}$ and $\mathrm{HCN}$ sampling line was identically controlled at $200 \mathrm{~mL} / \mathrm{min}$. Finally, other producer gases were collected by a gas bag after passing through filters to remove water for micro GC analysis.

\subsection{Analysis Methods}

After the experiments, the char left in the pyrolyzer was collected and weighed after the temperature of the pyrolyzer had cooled down to room temperature. The nitrogen contained in the char (Char-N) was analyzed by a CHNS element analyzer (VARIO MACRO CHNS analyzer with an oxygen kit; Elemenar Co., Hanau, Germany). The reproducibility of all data for char yield was $\pm 1.0 \%$ for all experiments while the reproducibility of Char-N production was about $\pm 4.0 \%$ due to the analysis error caused by the small amount sample used $(2 \mathrm{mg})$ for each analysis and the CHNS element analyzer and the non-uniform properties of the industrial biomass wastes. In order to investigate the nitrogen functional group changes during the pyrolysis reactions, some part of the char was analyzed by FTIR (BRUKER TENSOR 27; Bruker Optics Co., Billerica, MA, USA) to compare with raw biomass fuels.

The tar collected in the cold trap was firstly washed by acetone and then the solution was evaporated by the rotary evaporator (XWD Rotary Evaporator V-3003S; Beijing Zhonglian Keyi Co., Beijing, China) to separate the tar from acetone. As the boiling point of acetone is low $\left(56{ }^{\circ} \mathrm{C}\right)$, only a little light tar was lost during the evaporation. Then the nitrogen content in the tar was also measured by the CHNS element analyzer. Due to the difficulties of tar collecting caused by the washing and evaporation steps, the reproducibility of tar yield and Tar- $\mathrm{N}$ content was about $\pm 4.0 \%$ and $\pm 6.2 \%$ for repeated runs. Also some part of the tar solution was injected into the GC-MS (Agilent 6890GC/5792MS; Agilent Technologies Co., Santa Clara, CA, USA) to identify the main nitrogenous tar compounds. 
After finishing sampling, $\mathrm{NH}_{3}$ and $\mathrm{HCN}$ in the solutions were quantified by the ion potential method using a PH/ISE meter (Orion 4STAR; Orion Co., Beverly, MA, USA) with an ammonia selective electrode (Orion 9512HPBNWP; Orion Co.) and a $\mathrm{CN}^{-}$selective electrode (Orion 9406; Orion Co.), respectively. Ion potential analyses with the selective electrodes were usually used for measurement of $\mathrm{NH}_{3}$ and $\mathrm{HCN}$ in the literatures [6,9,22] due to its easy operation and good reproducibility $( \pm 2.0 \%)$. Other producer gases collected in gas bags were identified and measured by the micro GC (Agilent GC 3000; Agilent Technologies Co.).

\section{Results and Discussion}

\subsection{Pyrolysis Products}

During the pyrolysis of biomass, the Fuel-N is mainly released as nitrogen volatile compounds (tar) and nitrogen containing gases $\left(\mathrm{NH}_{3}, \mathrm{~N}_{2}, \mathrm{HCN}, \mathrm{HNCO}\right)$ while the rest is retained in the resultant solid or char. In order to clearly identify the $\mathrm{N}$ species in various pyrolysis products, it is essential to firstly determine the yields of pyrolysis products under different pyrolysis conditions.

Figure 2 presents pyrolysis products as a function of pyrolysis temperature with two pyrolysis methods. It is clear seen that above $500{ }^{\circ} \mathrm{C}$, char yields slowly decrease with the increase of the pyrolysis temperature. Taking sludge $\mathrm{A}$ as an example, the pyrolysis of sludge $\mathrm{A}$ at $400{ }^{\circ} \mathrm{C}$ obviously exhibited a char production that abruptly decreased by increasing the temperature from $400{ }^{\circ} \mathrm{C}$ to $500{ }^{\circ} \mathrm{C}$. This can be explained by the fact that volatile components such as oxygen, hydrogen were released in significant amounts at a temperature as low as $500{ }^{\circ} \mathrm{C}$ [23]. This was also verified by the sudden increase of the tar yield observed in this interval. However, char yields in Figure 2 have not reached a constant value in the studied temperature range, while as reported the weight loss of coal can approach a final constant value at a temperature of nearly $1400 \mathrm{~K}$. That may be attributed to little oxidization of biomass or the properties of some volatile part which is still left in char phase at $800{ }^{\circ} \mathrm{C}$. It was confirmed by the thermogravimeric analysis of char obtained in rapid pyrolysis of sludge $\mathrm{A}$ at $800{ }^{\circ} \mathrm{C}$, that it still showed about $1.8 \mathrm{wt} \%$ volatile components. In terms of the rapid pyrolysis, with the increase of the temperature $\left(>500{ }^{\circ} \mathrm{C}\right)$, tar production clearly decreased due to the directly rupture and breakage of large molecules caused by a higher temperature and a high heating rate. In the case of the slow pyrolysis, the tar yield did not change a lot by increasing the temperature and just slightly decreased due to the thermal cracking of some primary tars. However, contrary to our expectations, the reduction of tar with the increase of the temperature for the slow pyrolysis was not as large as that for the rapid pyrolysis regardless of any longer tar residence time. That probably can be due to the weak tar cracking of the initial pyrolysis period at a low temperature [24]. In this study, with the programmed increase of the temperature, the primary tar evolved from the solid phase from $400{ }^{\circ} \mathrm{C}$ was not sufficiently cracked due to the low heat flux. At the same time, as the quartz plate was set up near the bottom of the outlet, most of that tar was quickly purged out to the tar tap with the carrier gas before the temperature was raised up to the final pyrolysis temperature. As a result, the tar reduction in the slow pyrolysis is much less sensitive to the final pyrolysis temperature than that in the rapid pyrolysis. The gas yield shown in Figure 2, was to the complement of the char and tar yield. 
Figure 2. Pyrolysis products as a function of the pyrolysis temperature with two pyrolysis methods: SA is the sludgeA produced in Beijing, SB is the sludgeB produced in Inner Mongolia, MW is the mycelial waste from antibiotic production.
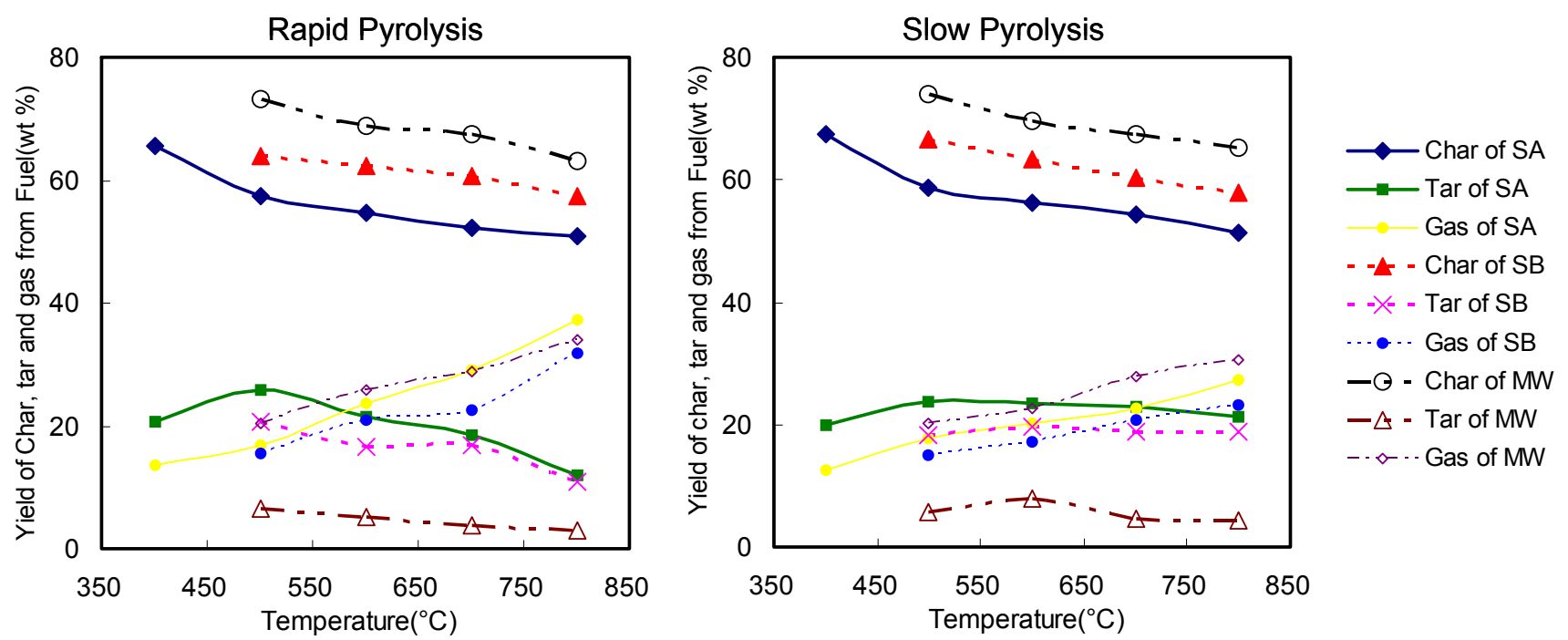

\subsection{Fuel-N Conversion to Char-N}

In the combustion or gasification, following to the primary pyrolysis, the nitrogen content in char (Char-N) mainly forms NO while the nitrogen content in volatiles (volatile-N) contributes to the formation of $\mathrm{NO}$ and $\mathrm{N}_{2} \mathrm{O}$ which are also the dominant part of $\mathrm{NO}_{\mathrm{x}}$ emissions. Therefore, it is very important to investigate the $\mathrm{N}$ species in the primary pyrolysis products.

The yield of Char-N obtained after a series of pyrolysis experiments is shown in Figure 3. Regardless of the type of biomass fuel, the change of Char- $\mathrm{N}$ yield with the pyrolysis temperature shows the same trend and greatly decreases with the increase of the pyrolysis temperature. This trend also agreed well with the results of pyrolysis of various biomass and coal samples in the literature $[4,9,16,25]$. Compared with Figure 2, it is seen that the nitrogen loss in char vs. the temperature is larger than the weight loss of char. Moreover, compared with sewage sludge (SA and SB), the descending slope of Char-N in mycelial waste with the increase of the pyrolysis temperature is much larger. It was also suggested that during the pyrolysis progress, the effect of temperature on the Char-N distribution of mycelial waste was much more sensitive than that of sewage sludge. Besides that, in the researched temperature range, more Char-N was observed for mycelial waste than that for sewage sludge and the difference between them diminished with the increase of the pyrolysis temperature. The difference of the amount of the Char-N yield may be explained by the different characteristics of the feedstocks. It was confirmed by the slow pyrolysis experiments of biomass that the volatile matter started to be released at around $300{ }^{\circ} \mathrm{C}$ for sewage sludge and $400{ }^{\circ} \mathrm{C}$ for mycelial waste, respectively. When the pyrolysis temperature was high enough $\left(\geq 700{ }^{\circ} \mathrm{C}\right)$, almost all the volatile-N was released so that the difference in the Char-N amount between them became smaller and the pyrolysis temperature was the predominant parameter which influenced the distribution of Char-N. 
Figure 3. Yield of Char-N after a series of pyrolysis.

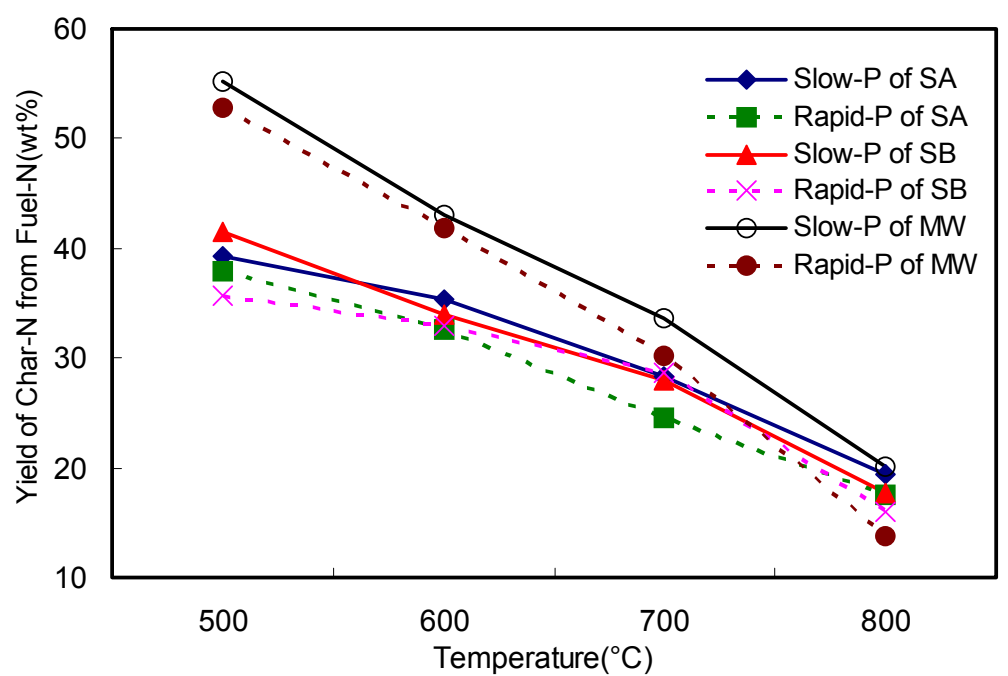

As Figure 3 shows, comparing different pyrolysis methods of the same biomass in the same temperature range $\left(500-800{ }^{\circ} \mathrm{C}\right)$, it is demonstrated that a little more Char-N was left in the slow pyrolysis of biomass. The same results were also found in the report of Aznar et al. [4] during the pyrolysis of dried sewage sludge. It can be explained that the longer residence time of the char phase (at least for $80 \mathrm{~min}$ in the pyrolysis at $500{ }^{\circ} \mathrm{C}$ ) during the slow pyrolysis than that during the rapid pyrolysis, which may result in a little more Fuel-N being left in the char part. As reported [16,26], the mechanisms of Char-N reactions are complicated due to the competition between Char- $\mathrm{N}$ formation and $\mathrm{N}$ liberation from char. For the three kinds of biomass fuels, the Fuel-N mainly existed in the form of protein. According to the research concerning protein pyrolysis [27,28], linear amides produced from the protein pyrolysis can react with each other to induce the formation of double bonds between carbon and nitrogen in the solid residue. On the other hand, another crucial reaction leading to the formation of Char-N is the cross-linking between side-groups due to the reactive side chains of proteins. Becidan et al. [16] also reported that the Maillard reactions between peptides and proteins with free amino groups could lead to a collection of Char-N products. However, the difference between the rapid pyrolysis and the slow pyrolysis is not very distinctive. It may be that $\mathrm{N}$ species are discharged from char under the effects of radicals produced from volatiles. Hence more detailed information about the functional groups of the biomass and obtained char should be considered because Fuel-N release has a close relationship with the N-function form of fuels according to many researchers $[4,9,29]$.

FTIR analysis, as one of usual methods to determine the functional groups of char produced by pyrolysis [4,21], was also used for the three kinds of biomass and char obtained using the rapid and slow pyrolysis in $700{ }^{\circ} \mathrm{C}$. The assignment of the principal IR absorption bands is shown in Table 2 . Figure 4A shows the FTIR spectra of the three samples and suggests that the major nitrogen functional groups of these biomass samples are similar. It is possible that the origin of the organic matter for them is quite similar due to the presence of dead microorganisms like bacteria or other species, which are responsible for the removal of the waste organic matter from water and producing antibiotic materials. Hence Fuel-N in sewage sludge or mycelia waste would mainly be present in the dead microbial cells (e.g., nucleic acids and proteins). 
Table 2. Assignment of the principal IR absorption bond [4,19,30-32].

\begin{tabular}{cc}
\hline Wavelength $\left(\mathbf{c m}^{-\mathbf{1}}\right)$ & Typical functional group \\
\hline $3100-3600$ & $\mathrm{O}-\mathrm{H}, \mathrm{N}-\mathrm{H}$ \\
2900 & $\mathrm{C}-\mathrm{H}$ \\
$2220-2300$ & $\mathrm{C}=\mathrm{N}, \mathrm{C} \equiv \mathrm{N}$ \\
$1712-1720$ & $\mathrm{C}=\mathrm{O}$ stretching (conjugate) \\
1650 & Amide I \\
$1540 / 1556-1560$ & Amide II/COO \\
\hline
\end{tabular}

Figure 4. FTIR spectra of biomass and char: $\mathbf{A}$ is for three kinds of biomass; $\mathbf{B}$ is for char obtained after the rapid and slow pyrolysis at $700{ }^{\circ} \mathrm{C}$.

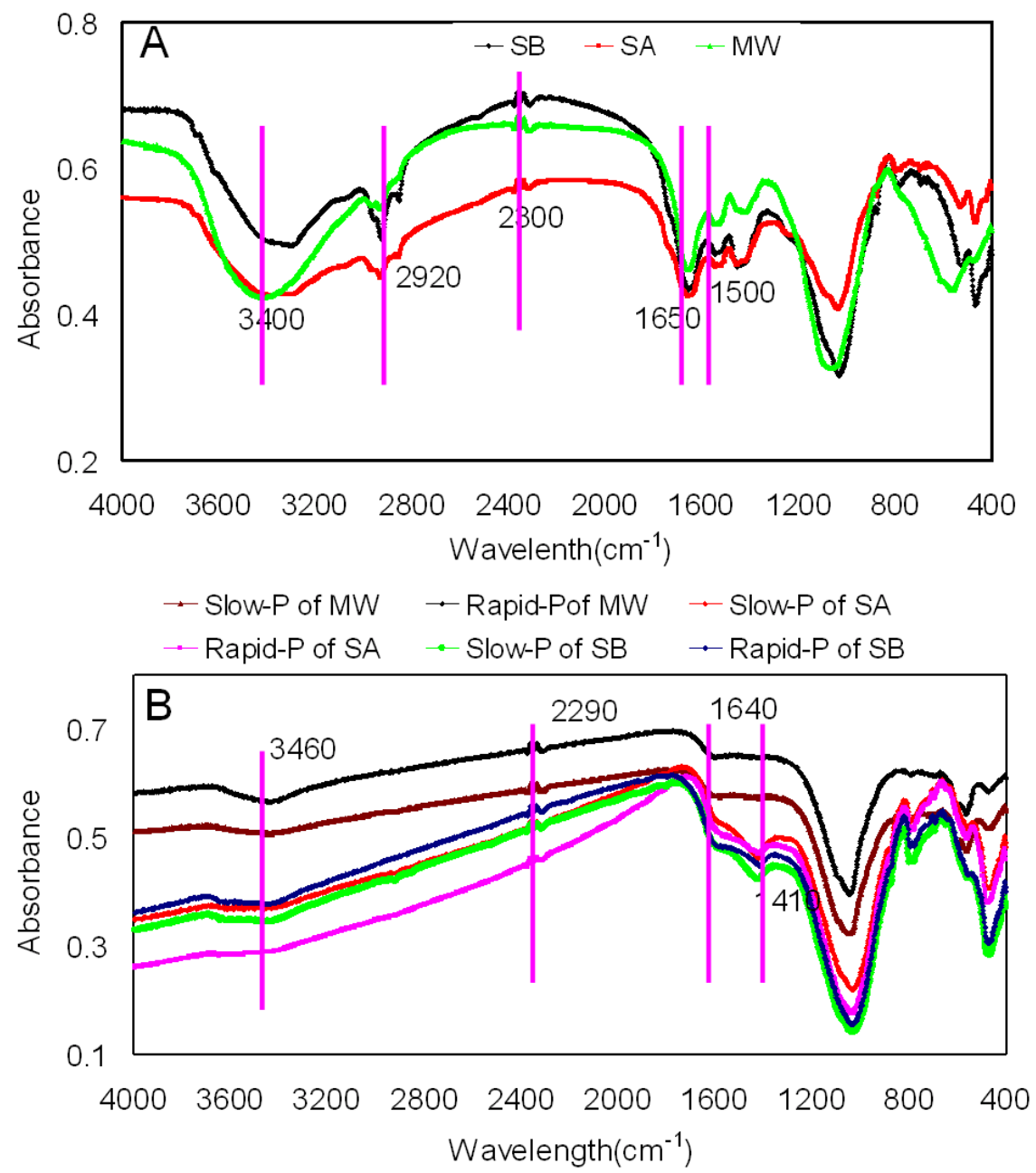

Compared with the FTIR spectrum in Figure 4A, the spectrum of char shown in Figure 4B after the pyrolysis was much simpler. In Figure 4B, a broad band located at $3100-3600 \mathrm{~cm}^{-1}$ was greatly reduced. As Table 2 shows, this band is regarded as $\mathrm{H}$-bonded $\mathrm{O}-\mathrm{H}$ or $\mathrm{N}-\mathrm{H}$ groups. The same phenomenon was also observed by Aznar et al. [6] and it was explained that some N-H bond probably was removed and broken up to be released as Volatile-N. Also in Figure 4A, two major typical peaks of nitrogen-containing groups were observed at 1650 and $1540 \mathrm{~cm}^{-1}(\mathrm{C}=\mathrm{O} /$ amide I and amide II, respectively), which were regarded as characteristic peaks of protein structures $[4,33]$. It was clear that after the pyrolysis, these two typical bonds disappeared in the spectrum of char as indicated in Figure 4B. 
It might be that protein is easy to be decomposed to volatile such as tar or contributes to char formation as mentioned above during the pyrolysis. However, because with FTIR it is difficult to exactly identify the functional groups which are displayed at the same wavelength number such as the bands detected in the $3100-3600 \mathrm{~cm}^{-1}$ and $1650 \mathrm{~cm}^{-1}$ regions, a detailed $\mathrm{N}$ functional analysis of the biomass or char with other powerful analysis methods should be conducted in future research.

\subsection{Fuel-N Conversion to Volatile-N}

\subsubsection{Fuel-N Conversion to Tar-N}

At present, there is little information about nitrogen contained in $\operatorname{tar}(\operatorname{Tar}-\mathrm{N})$ and the chemical form of nitrogenous tar compounds due to the difficulties of tar collection. Figure 5 displays the variation of Tar-N yield after a series of pyrolysis of different biomass samples in the temperature range of $500-800{ }^{\circ} \mathrm{C}$.

Figure 5. Tar-N yield during a series of pyrolysis experiments.

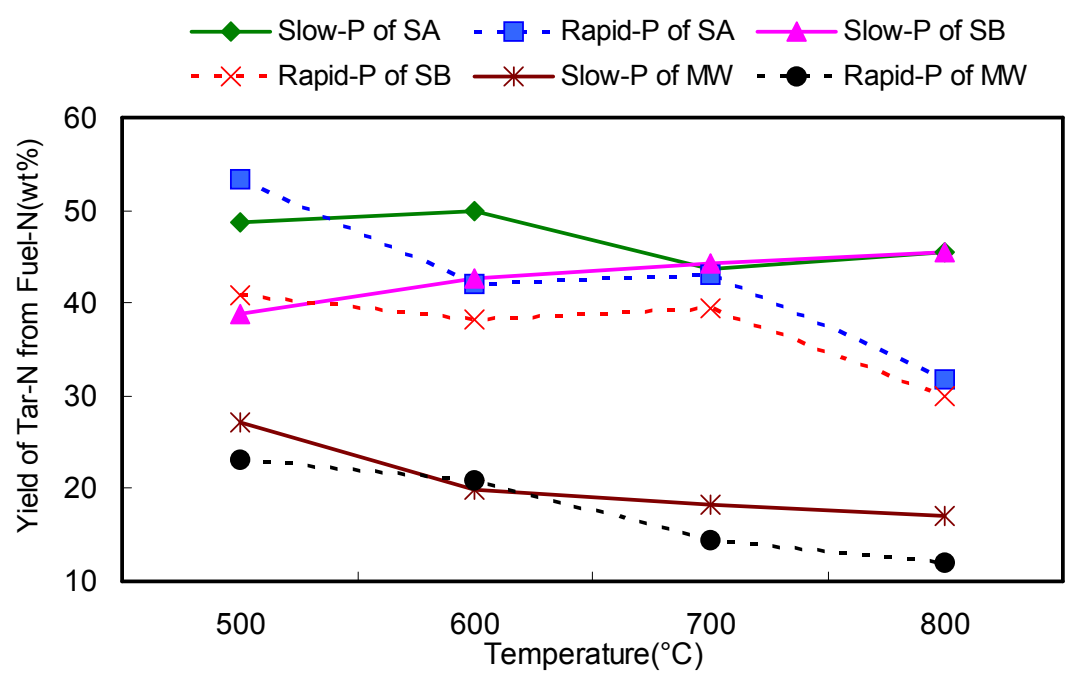

For the rapid pyrolysis of biomass, the yield of Tar-N obviously decreased with the increase of the pyrolysis temperature, especially at temperatures above $700{ }^{\circ} \mathrm{C}$. In this study, when fuels fell down to the bottom distributor from the top of the reactor in the case of the rapid pyrolysis, particles of biomass fuels were equally and fully heated up to produce tar and release $\mathrm{N}$ species instantaneously. Thus when it reached the higher temperature, the more intensive rupture of chemical bonds produced smaller molecules such as nitrogenous gases. However, in the case of the slow pyrolysis, at a high temperature $\left(700-800^{\circ} \mathrm{C}\right.$ ), the Tar-N amounts are still large, which is similar to the trends of tar yield as a function of the pyrolysis temperature because nitrogen is bound to the tar compounds. Except for the reasons discussed above, the complexity of nitrogenous tar compounds formation should be also considered. In our previous study on nitrogenous tar formation from sewage sludge pyrolysis through GCMS [34], it was found that the major part of $\mathrm{N}$-tar compounds were cyanoaromatic compounds at $800{ }^{\circ} \mathrm{C}$. As reported cyanoaromatic compounds could be formed in two different ways: from the dehydrogenation of amino group in proteins or from hydrogen cyanide $(\mathrm{HCN})$ addition to light aromatic hydrocarbons. Thus, larger Tar-N at a higher temperature may partly be attributed to the homogenous reaction 
between light tar compounds and $\mathrm{HCN}$, which is promoted by the increased amount of $\mathrm{HCN}$ with the rising temperature.

As shown in Figure 5, being independent of the heating rate, the yield of Tar-N produced from mycelial waste is much lower than that from sewage sludge in the current temperature range. The yield of Tar-N for different biomasses, can be roughly arranged in the order of SA $>$ SB $>$ MW. It is well known that tar production can be correlated with the volatility of fuels and fuels with higher volatile matter may release more tar. For Tar-N, the amount may also depend on the volatile matter and nitrogen content of fuels. In the researches of Dong et al. [35] and Zhao et al. [36], it was reported that $\mathrm{NO}$ emissions in combustion of biomass or biomass-coal blend were closely related to the Fuel-N parameter $\mathrm{VN}$ and the Fuel-N conversion to NOx conversion for coal combustion varied almost linearly with the Fuel-N parameter VN, respectively, where VN was identified and calculated by the following Equation (1):

$$
\mathrm{VN}=100 \mathrm{~V} \mathrm{~N}[35,36]
$$

where $\mathrm{VN}-$ Volatile- $\mathrm{N}$ ratio of fuel, $\%$; V-Volatile percentage of fuel, $\%$; $\mathrm{N}$-Nitrogen percentage of fuel, $\%$.

Thus in Figure 6, the Tar-N yield from Fuel-N versus the Fuel-N parameter VN for temperature range of $500-800{ }^{\circ} \mathrm{C}$ in the rapid and slow pyrolysis also was presented in order to investigate the relationship between fuel type and Tar- $\mathrm{N}$ yield.

Figure 6. Tar-N yields from Fuel-N versus the Fuel-N parameter VN.
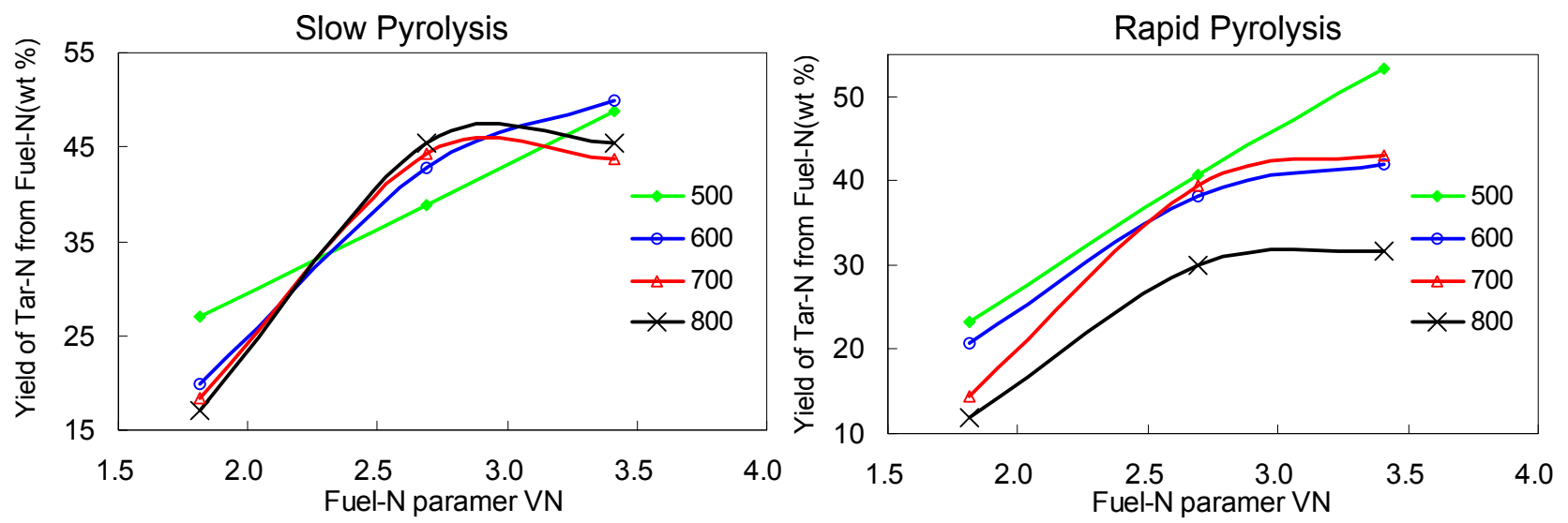

According to the biomass properties shown in Table 1 and Equation (1), the value of VN was calculated to be in the order of SA $>$ SB $>$ MW, which was in accordance with the order of Tar-N yields. However, it can be seen from Figure 6, only at $500^{\circ} \mathrm{C}$ Tar-N yield increased linearly with the VN value whereas Tar-N production was just slightly enhanced, although the VN value greatly increased for SA compared with SB in the temperature range of $600-800{ }^{\circ} \mathrm{C}$. That may be attributed to the different characteristics of nitrogen functional forms in biomass like thermal stability, especially at a high pyrolysis temperature. Kambara et al. [9] had measured the nitrogen retained in char after the rapid pyrolysis of 20 coals and observed that two kinds of coals whose volatile matter and nitrogen amount were the same, while the behavior of their volatile nitrogen loss as a function of the temperature was quite different. Therefore, under the conditions tested in this study, the Tar- $\mathrm{N}$ as one part of volatile-N produced from different biomass may have certain relevance with the VN value from 
the proximate and ultimate analysis of biomass, but it still should be comprehensively discussed on the basis of other characteristics of biomass such as nitrogen functional forms.

Based on the above considerations, further knowledge about the chemical forms of the nitrogenous tar was also needed and GC-MS was used to analyze the major nitrogenous tar compounds produced from the pyrolysis of biomass. Figure 7 displays the nitrogenous tar compounds produced from the pyrolysis of sludgeA, sludgeB and mycelial waste at the temperature of $700{ }^{\circ} \mathrm{C}$ with the different pyrolysis methods. In Figure 7, the peaks with a data mark are nitrogenous tar compounds identified by the GC-MS. It is well known that tar formation is highly dependent on the reaction conditions and biomass fuels.

Figure 7. Major nitrogenous tar compounds identified by the GC-MS.
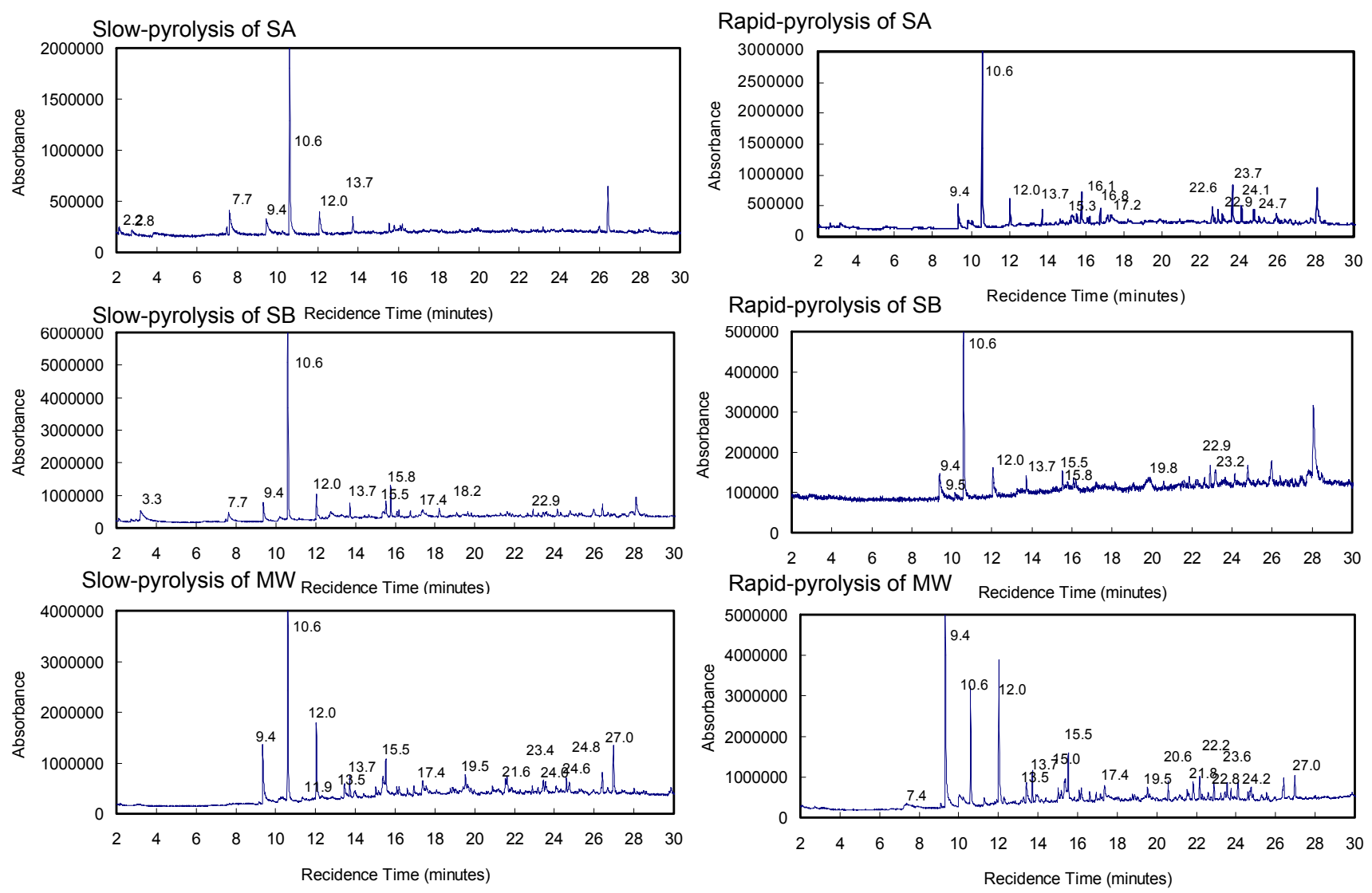

As shown in Figure 7, under the same pyrolysis conditions, the species of nitrogenous tar compounds from mycelia waste are more than that from sludge, although the total Tar-N yield of mycelial waste in Figure 5 is less than that of sludge. Mycelia waste is prone to form large molecule nitrogenous tar compounds. Based on the retention time of peaks, some identical peaks marked with $9.4 \mathrm{~min}, 10.6 \mathrm{~min}$ and $12 \mathrm{~min}$ are also shown in all mass spectrogram and could be identified as typical nitrogenous tar compounds during the pyrolysis of the same classification of industrial biomass wastes. In addition, the chemical structures of those nitrogenous tar compounds shown in Figure 8a indicate that the major nitrogenous tar compounds are N-heteroaromatic compounds. Actually, besides those nitrogenous tar compounds, other typical nitrogenous tar compounds from biomass displayed in Figure $8 \mathrm{~b}$ also indicates that most of nitrogenous tar compounds exists as N-heteroaromatic 
compounds with carbonyl or hydroxyl, suggesting that those tar compounds mainly come from complex decomposition processes of the proteins in the biomass.

Figure 8. Chemical structures of major nitrogenous tar compounds produced from different biomass: (a) is chemical structures of same nitrogenous tar compounds from different biomass; (b) is chemical structures of other N-tar compounds).

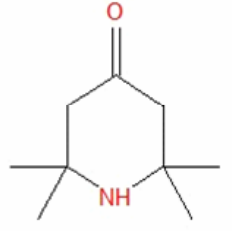

4-Piperidinone,2,2,6,6-tetramethyl-<smiles>CC1C(=O)CCN(C)C1C</smiles>

\section{1,2,3-Trimethylpiperidin-4-one}<smiles>CC1C(=O)CCN2CCCCC12</smiles>

Piperidin-4-one,1-ethyl-2,3-dimethyl-

(a)<smiles>COc1cc2c(cc1OC)C(O)C1(C)CCC2CN1</smiles><smiles>O=C(O)C1CCCC(C(=O)O)N1</smiles><smiles>CC1CCCCN1c1ccc([N+](=O)[O-])cc1F</smiles><smiles>CC(=O)N(C)CC#CCN1CCC(O)C1</smiles><smiles>c1ccc(C2=NCC3(CCCCC3)O2)cc1</smiles><smiles>CCCC/C(C)=N/Nc1ccc([N+](=O)[O-])cc1[N+](=O)[O-]</smiles><smiles></smiles><smiles>CCCC12CN3CCN(CC(C)(C3)C1O)C2</smiles><smiles>O=C(CCc1ccc(O)cc1)NCCc1c[nH]c2ccccc12</smiles>

(b)

\subsubsection{Fuel-N Conversion to $\mathrm{NO}_{\mathrm{x}}$ Precursor Gases}

As mentioned above, during the pyrolysis of biomass, the Fuel-N conversion to nitrogenous gases includes the formation of $\mathrm{NH}_{3}, \mathrm{HCN}, \mathrm{N}_{2}, \mathrm{HNCO}$ and also little amount of $\mathrm{NO}$. Based on abundant research $[4,6,13,14,16], \mathrm{NH}_{3}$ and $\mathrm{HCN}$ were identified as major $\mathrm{NO}_{\mathrm{x}}$ precursor gases during the pyrolysis. In this study, $\mathrm{NH}_{3}$ and $\mathrm{HCN}$ were measured as major $\mathrm{NO}_{\mathrm{x}}$ precursors and the effects of pyrolysis parameters on their formation and the Fuel-N distribution to their parts were discussed. As for HNCO gas, it was not detected in this study due to the minor production from the pyrolysis of biomass. $\mathrm{HNCO}$ can also be hydrolyzed into $\mathrm{NH}_{3}$ through the reaction of $\mathrm{HNCO}+\mathrm{H}_{2} \mathrm{O} \rightarrow \mathrm{NH}_{3}+\mathrm{CO}_{2}$ in the wet sampling systems used in this study.

Figure 9 shows the conversion of Fuel-N into $\mathrm{NH}_{3}$ and $\mathrm{HCN}$ during a series of pyrolysis experiments. It was found that nitrogen distribution in the form of $\mathrm{NH}_{3}$ and $\mathrm{HCN}$ was different for different pyrolysis heating rates. The reasons for those variant phenomena should be investigated based on the formation processes of $\mathrm{HCN}$ and $\mathrm{NH}_{3}$, the Char- $\mathrm{N}$ selectivity toward $\mathrm{HCN}$ and $\mathrm{NH}_{3}$ and the properties of different biomass sources. Different pathways leading to the formation of $\mathrm{NH}_{3}$ during the pyrolysis 
were already summarized in our previous work and other studies [34,37-39]. The first one is that nitrogen in proteins and amino acids may be released in the form of $\mathrm{NH}_{3}$ in the temperature range of $300-500{ }^{\circ} \mathrm{C}$. The second one is the thermal cracking of volatile and char by undergoing the secondary reactions. The last one is the hydrolysis and hydrogenation of HCN on the surface of char or the hydrogenation of Char-N with $\mathrm{H}$ radicals. As for $\mathrm{HCN}$ production, the protein firstly leads to the release of volatile cyclic amides and then the cyclic amides are cracked into HCN [34,40]. It was also reported that the thermal cracking of volatile- $\mathrm{N}$ was the main route for the formation of HCN while only small amount was formed from the breakdown of relatively unstable $\mathrm{N}$-containing structures in char.

Figure 9. Fuel $\mathrm{N}$ conversion to $\mathrm{HCN}$ and $\mathrm{NH}_{3}$ during a series of pyrolysis of biomass.
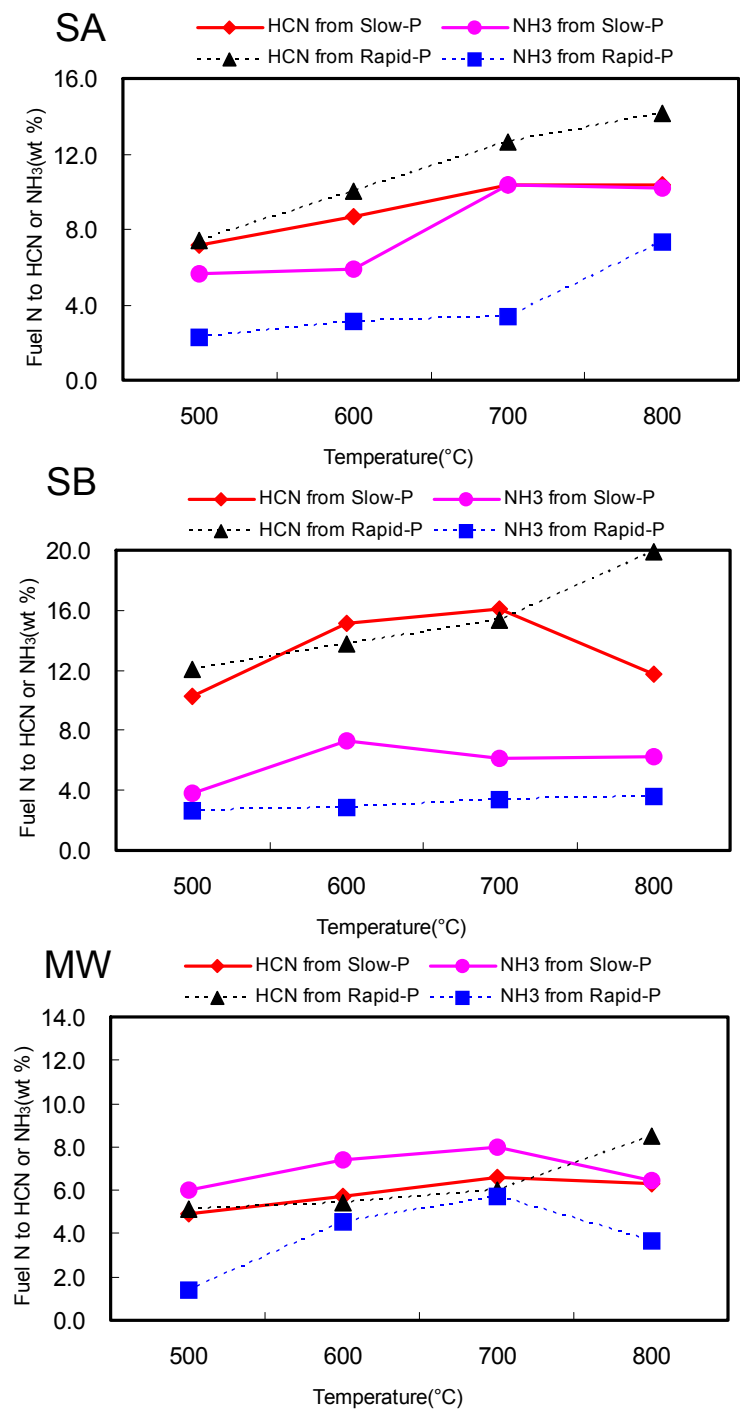

In Figure 9, for the rapid pyrolysis of biomass, $\mathrm{HCN}$ was the predominant $\mathrm{NO}_{\mathrm{x}}$ precursor for the different biomass types and obviously increased with the increasing temperature, especially for the two kinds of sewage sludge. It was acceptable that at higher temperature, the ring scission took place instantaneously and became prevalent while the biomass was dropping into reactor, resulting in the release of more volatile-N. That also can be proved by Figure 3, where less Char-N was left for the rapid pyrolysis at a higher temperature. As reported above or in the work [14], most of the HCN was produced from the volatile-N resulting in more HCN being produced for the rapid pyrolysis at a higher 
temperature. However, the temperature dependence of the Fuel-N conversion to $\mathrm{NH}_{3}$ seems to be complicated. In terms of sludge, $\mathrm{NH}_{3}$ released from both of sludge $\mathrm{A}$ and sludgeB increased with the temperature while $\mathrm{NH}_{3}$ released from mycelia waste firstly increased with the temperature and then decreased at $800{ }^{\circ} \mathrm{C}$. That may be attributed to the impact of other processes involved in $\mathrm{NH}_{3}$ formation. As Figure 3 shows, at $700{ }^{\circ} \mathrm{C}$, the maximum amount of Char-N of mycelial waste was still left compared to sludge and then Char-N amount abruptly became the minimum after the pyrolysis at $800{ }^{\circ} \mathrm{C}$. It suggested that at $700-800{ }^{\circ} \mathrm{C}$, largest volatile-N discharged, which might mainly form to $\mathrm{HCN}$ instead of $\mathrm{NH}_{3}$, leading to the drop of $\mathrm{NH}_{3}$. The effect of the temperature on $\mathrm{NH}_{3}$ during the pyrolysis is often reported that N-release as $\mathrm{NH}_{3}$ is increasing with the temperature but reaches a maximum (at $800{ }^{\circ} \mathrm{C}$ for cane trash [18], at $825-900{ }^{\circ} \mathrm{C}$ for thermally thick samples [16], at 1,218 $\mathrm{K}$ for typical coals [9]) before stabilizing or decreasing at a higher temperature [16,38]. The differences just exist in the temperature range for the plateau value of $\mathrm{NH}_{3}$ according to the characteristics of fuels.

In the case of the slow pyrolysis of different biomass, the Fuel-N conversion to $\mathrm{NH}_{3}$ and $\mathrm{HCN}$ showed inconsistent behavior. As Figure 9SA shows, $\mathrm{HCN}$ is a little more than $\mathrm{NH}_{3}$ in the slow pyrolysis of sludge, while $\mathrm{HCN}$ is much more than $\mathrm{NH}_{3}$ in the slow pyrolysis of sludge, as shown in Figure 9SB. Contrary to sewage sludge, for the slow pyrolysis of $\mathrm{MW}, \mathrm{NH}_{3}$ gas become the main $\mathrm{NO}_{\mathrm{x}}$ precursor, which is more than HCN in Figure 9MW. The reasons can be that the reactions were more intricate due to the longer residence time of the solid and gas phases. At the primary step of the pyrolysis at a lower temperature, some amount of char was formed in the reactor. Moreover, according to the study of Tian et al. [14], it was reported that the volatiles released during the pyrolysis contained $\mathrm{H}$-rich structures. With the increase of the temperature, $\mathrm{HCN}$ was continually released from volatile and some $\mathrm{H}$ radicals were also formed from the released volatile containing H-rich structures. Then additional $\mathrm{NH}_{3}$ was produced through the third kind reactions of $\mathrm{NH}_{3}$ formation described above, where the released $\mathrm{HCN}$ can be converted into $\mathrm{NH}_{3}$ when passing through nascent char or the hydrogenation of nascent Char- $\mathrm{N}$ to $\mathrm{NH}_{3}$ caused by $\mathrm{H}$ radicals. However, for the rapid pyrolysis, when biomass was supplied into the reactor, most of volatiles are instantaneously released and purged out from char surfaces by the carrier gas. The residence time of char and gas phases was too short to supply additional $\mathrm{NH}_{3}$ production. This can also be proved by Figure 9. During the rapid pyrolysis of different biomass, less $\mathrm{NH}_{3}$ gas was observed than that during the slow pyrolysis. Therefore, during the pyrolysis of biomass, not only the formation process of $\mathrm{HCN}$ and $\mathrm{NH}_{3}$ but also the selectivity of Char-N to $\mathrm{HCN}$ and $\mathrm{NH}_{3}$ should be comprehensively considered, especially for the slow pyrolysis.

In addition, the selectivity of Char-N to $\mathrm{HCN}$ and $\mathrm{NH}_{3}$ mainly depends on the two key elements which promote additional $\mathrm{NH}_{3}$ production: $\mathrm{H}$ radical formation and nascent char formed at lower temperature. The $\mathrm{H}$ radical formation has an osculating relationship with the properties of biomass. In some researches [14,26,37], it was reported that the oxygen content and the $\mathrm{O} / \mathrm{N}$ ratio of fuel affected the partition of $\mathrm{HCN}$ and $\mathrm{NH}_{3}$. It was claimed that a high oxygen content in biomass would produce significant amounts of $\mathrm{H}_{2} \mathrm{O}$ and other O-containing species as pyrolysis products [14]. In that case, additional $\mathrm{H}$ radicals can be generated from "self-gasification" of biomass by inherent moisture and pyrolytic water. During the experiments of mycelial waste in the slow pyrolysis, though samples had been dried to lower the moisture content $(0.3 \mathrm{wt} \%$, received basis $)$, much pyrolytic water produced from the pyrolysis process could be clearly observed. Hence it can be assumed that more additional $\mathrm{H}$ radicals are possible to be generated from "self-gasification" of mycelia waste by pyrolytic water. As 
discussed above, $\mathrm{H}$ radicals can promote the third kind reaction of additional $\mathrm{NH}_{3}$ formation resulting in the changes of the selectivity of total Fuel-N towards $\mathrm{HCN}$ and $\mathrm{NH}_{3}$ especially for the slow pyrolysis which can supply nascent char in a long residence time. In this study, according to Table 1, the oxygen content and the $\mathrm{O} / \mathrm{N}$ ratio of three samples were calculated and the order was determined as $\mathrm{MW}>\mathrm{SA}>\mathrm{SB}$. It can be deduced that more additional $\mathrm{NH}_{3}$ would be produced in the slow pyrolysis of mycelia waste and sludgeA than that of sludgeB so that the total Fuel-N selectivity towards HCN and $\mathrm{NH}_{3}$ was even changed. Therefore Fuel-N of mycelia waste is prone to release more $\mathrm{NH}_{3}$ than $\mathrm{HCN}$ for the slow pyrolysis. Based on above investigation, it can be concluded that the heating rate of pyrolysis and the oxygen content or the $\mathrm{O} / \mathrm{N}$ ratio of biomass have great effects on the Fuel-N conversion to $\mathrm{HCN}$ and $\mathrm{NH}_{3}$ and a low heating rate of pyrolysis and the high oxygen content or the $\mathrm{O} / \mathrm{N}$ ratio of biomass are in favor of $\mathrm{NH}_{3}$ formation.

\subsection{Nitrogen Distribution}

After investigating the effects of the temperature and the heating rate on the formation of Char-N, Tar- $\mathrm{N}$ and $\mathrm{NO}_{\mathrm{x}}$ precursor gases during a series of pyrolysis of industrial biomass wastes with high nitrogen content, the integrated information of the Fuel-N migration process is given in Figure 10. In this study, after sampling tar and nitrogenous gases, the rest of the gases were collected by a gas bag and detected by a micro GC off-line. For the slow pyrolysis, it is impossible to collect all gas (including carrier gas) purged out from the reactor with a gas bag due to the long reaction time (at least $80 \mathrm{~min}$ at $500^{\circ} \mathrm{C}$ ). Thus only all gas produced from the rapid pyrolysis was analyzed by the micro GC (accuracy $\pm 1 \%$ ). Any small obstruction of $\mathrm{N}_{2}$ in air caused by the gas collection operation with a gas bag or gas pipe could even make it difficult to precisely determine the $\mathrm{N}_{2}$ amount owing to its low production at a low pyrolysis temperature while at a high pyrolysis temperature that effect can be neglected. Therefore, the remaining part of the nitrogen in Figure 10, mainly including $\mathrm{N}_{2}$, was obtained through the subtraction method for all pyrolysis experiment. And detailed nitrogen distribution of three biomass fuels with the rapid pyrolysis at $800{ }^{\circ} \mathrm{C}$ was specially shown in Table 3 .

Table 3. Fuel-N distribution of biomass in the rapid pyrolysis at $800^{\circ} \mathrm{C}$.

\begin{tabular}{|c|c|c|c|c|c|c|}
\hline \multirow{2}{*}{ Biomass } & \multirow{2}{*}{ Char-N, \% } & \multirow{2}{*}{ Tar-N, \% } & \multicolumn{3}{|c|}{ Gas-N, \% } & \multirow{2}{*}{ Detected total N, \% } \\
\hline & & & $\mathbf{N H}_{3}$ & HCN & $\mathbf{N}_{2}$ & \\
\hline SludgeA & 17.5 & 31.7 & 7.3 & 14.2 & 28.3 & 99.0 \\
\hline SludgeB & 16.0 & 29.9 & 3.6 & 19.9 & 33.7 & 103.1 \\
\hline Mycelia Waste & 13.9 & 11.9 & 3.7 & 8.5 & 55.8 & 93.8 \\
\hline
\end{tabular}

As shown in Figure 10, it could be found that at a lower temperature $\left(<800^{\circ} \mathrm{C}\right)$, Fuel-N was mainly converted into Char-N or Tar-N part for the pyrolysis of biomass in this study and the rapid pyrolysis was in favor of Fuel-N conversion to nitrogenous gases at a lower temperature compared with the slow pyrolysis. In terms of the two kinds of sewage sludge, it was shown that Fuel-N was mainly transformed into Tar- $\mathrm{N}$ in the studied temperature range of this work during the slow pyrolysis. As for sludgeA, Fuel-N conversion to Tar-N was about $44 \%-50 \%$ while $39 \%-45 \%$ Tar-N was formed for sludgeB. During the rapid pyrolysis, Fuel-N was firstly converted into the Tar-N part $(42 \%-53 \%$ for sludge $\mathrm{A}$ and $38 \%-41 \%$ for sludgeB) and then at $800{ }^{\circ} \mathrm{C}$ nitrogen in gaseous phase suddenly became 
the major part (51\% for sludgeA and 54\% for sludgeB). Regarding mycelial waste, at first, the Char-N (34\%-55\% for the slow pyrolysis and $42 \%-53 \%$ for the rapid pyrolysis) was the major part at a lower temperature and then nitrogenous gases became predominant either at $800{ }^{\circ} \mathrm{C}$ for the slow pyrolysis or from $700{ }^{\circ} \mathrm{C}$ for the rapid pyrolysis. From Table 3, it was seen that, the total summary for detected $\mathrm{N}$ in every part of pyrolysis products from the rapid pyrolysis at $800{ }^{\circ} \mathrm{C}$ was in the range of $93.8 \%-103.1 \%$. The fluctuation of total $\mathrm{N}$ may be mostly attributed to the tar recovery difficulty mentioned above.

Figure 10. Nitrogen distribution during a series of pyrolysis experiments.
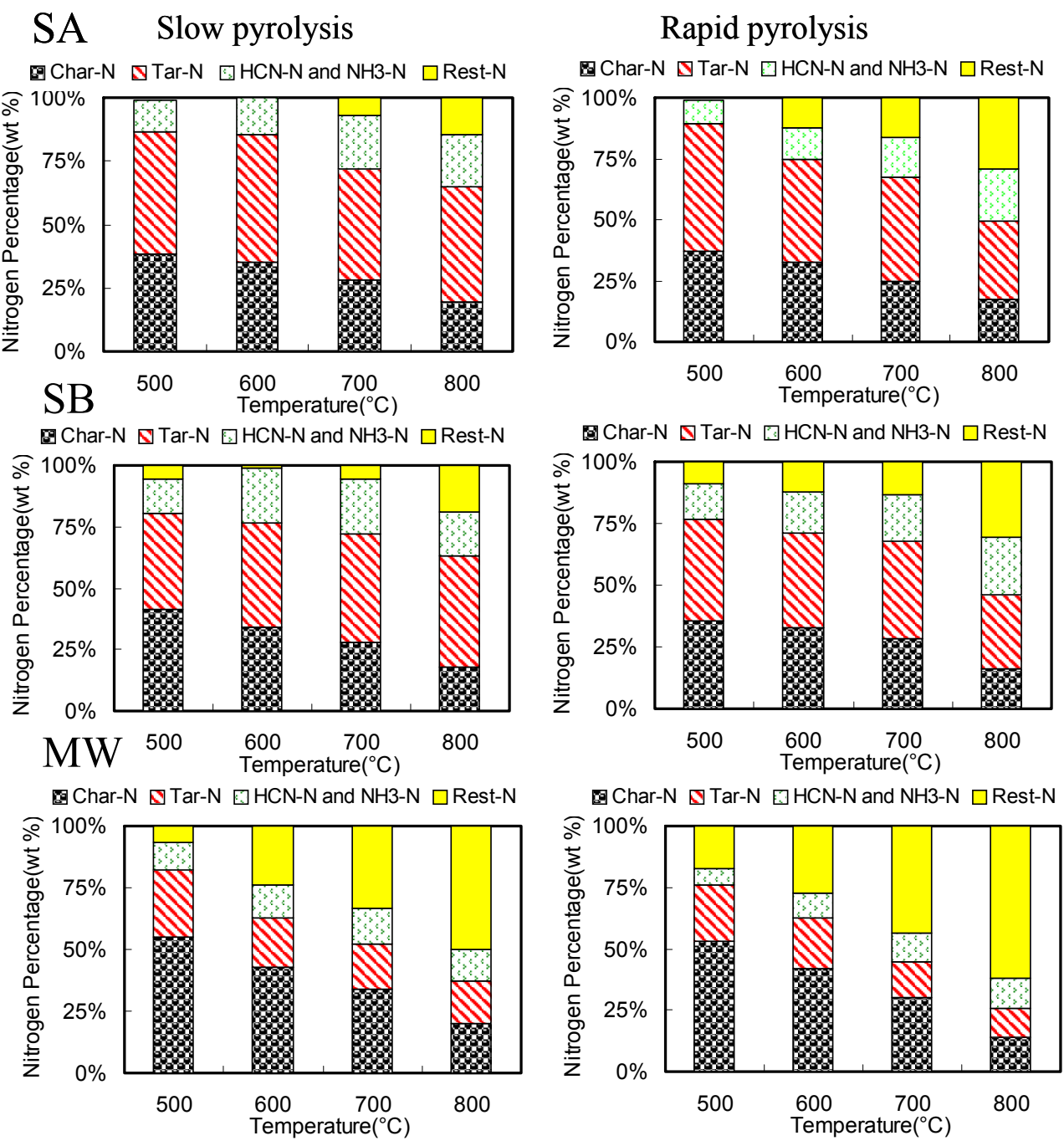

\section{Conclusions}

In this study, two typical industrial biomass wastes with high nitrogen content: sewage sludge and mycelial waste, were pyrolyzed to investigate the Fuel-N behavior at different pyrolysis temperatures and with different pyrolysis methods (rapid pyrolysis and slow pyrolysis). The following conclusions were obtained:

(1) Fuel-N conversion to Char-N strongly depended on the pyrolysis temperature and was more sensitive to temperature than char yield. The yield of Char-N was greatly reduced with the increase of the pyrolysis temperature independent of the heating rate and the type of high nitrogen content biomass. Comparing different biomass, more yield of Char-N was observed 
during the pyrolysis of the mycelial waste than that during the pyrolysis of sewage sludge. The heating rate of pyrolysis had small effects on Char-N production. After pyrolysis at $700{ }^{\circ} \mathrm{C}$, the characteristic peak for proteins disappeared in the FTIR spectrum of char.

(2) For the rapid pyrolysis of biomass, high pyrolysis temperature had a greater effect on Tar-N yield compared with the slow pyrolysis of biomass and reduced the amount of Tar-N. Under the same pyrolysis conditions, Tar-N production from different biomass was in the order of $\mathrm{SA}>\mathrm{SB}>\mathrm{MW}$, and might not only depend on the Fuel-N parameter VN but also on the functional forms of nitrogen in the biomass. According to the nitrogenous tar compounds identified by the GC-MS, $\mathrm{N}$-heteroaromatic compounds with carbonyls or hydroxyls were the characteristic compounds of the pyrolysis of high nitrogen content biomass at $700{ }^{\circ} \mathrm{C}$ which suggested that those nitrogenous tar compounds mainly come from complex reactions of protein in biomass.

(3) During the rapid pyrolysis of biomass, HCN was the predominant NOx precursor in the studied temperature range and increased with the increase of the temperature while the temperature dependence of $\mathrm{NH}_{3}$ seems to be complicated. In the case of the slow pyrolysis of mycelia waste, contrary to sewage sludge, $\mathrm{NH}_{3}$ was the main NOx precursor owing to a low heating rate of pyrolysis and a high oxygen content or $\mathrm{O} / \mathrm{N}$ ratio of biomass being in favor of additional $\mathrm{NH}_{3}$ formation.

(4) For nitrogen distribution, at first, Fuel-N was mainly converted into either Tar-N part for sewage sludge or Char-N part for mycelial waste in a relatively low temperature and then the gaseous phase nitrogen became the predominant part when the temperature was high enough.

\section{Acknowledgments}

This research work was supported by Strategic China-Japan Cooperative Program on "Science and Technology (S\&T) for Environmental Conservation and Construction of a Society with Less Environmental Burden" of the National Nature Science Foundation of China (No. 21161140329) and Japan Science and Technology Agency.

\section{References}

1. Mukadi, L.; Guy, C.; Legros, R. Prediction of gas emissions in an internally circulating fluidized bed combustor for treatment of industrial solid wastes. Fuel 2000, 79, 1125-1136.

2. Tan, L.L.; Li, C.Z. Formation of $\mathrm{NO}_{\mathrm{x}}$ and $\mathrm{SO}_{\mathrm{x}}$ precursors during the pyrolysis of coal and biomass. Part I. Effects of reactor configuration on the determined yields of $\mathrm{HCN}$ and $\mathrm{NH}_{3}$ during pyrolysis. Fuel 2000, 79, 1883-1889.

3. Xie, Z.; Feng, J.; Zhao, W.; Xie, K.C.; Pratt, K.C.; Li, C.Z. Formation of $\mathrm{NO}_{\mathrm{x}}$ and $\mathrm{SO}_{\mathrm{x}}$ precursors during the pyrolysis of coal and biomass. Part IV. Pyrolysis of a set of Australian and Chinese coals. Fuel 2001, 80, 2131-2138.

4. Aznar, M.; Anselmo, M.S.; Manyà, J.J.; Murillo, M.B. Experimental study examining the evolution of nitrogen compounds during the gasification of dried sewage sludge. Energy Fuels 2009, 23, 3236-3245.

5. Xie, K.C.; Lin, J.Y.; Li, W.Y.; Cheng, L.P.; Feng, J; Zhao, W. Formation of $\mathrm{HCN}$ and $\mathrm{NH}_{3}$ during coal macerals pyrolysis and gasification with $\mathrm{CO}_{2}$. Fuel 2005, 84, 271-277. 
6. Paterson, N.; Zhuo, T.; Dugwell, D.; Kandiyoti, R. Formation of hydrogen cyanide and ammonia during the gasification of sewage sludge and bituminous coal. Energy Fuels 2005, 19, 1016-1022.

7. Wójtowicz, M.A.; Pels, J.R.; Moulijn, J.A. The fate of nitrogen functionalities in coal during pyrolysis and combustion. Fuel 1995, 74, 507-516.

8. Li, C.Z.; Tan, L.L. Formation of $\mathrm{NO}_{\mathrm{x}}$ and $\mathrm{SO}_{\mathrm{x}}$ precursors during the pyrolysis of coal and biomass. Part III. Further discussion on the formation of $\mathrm{HCN}$ and $\mathrm{NH}_{3}$ during pyrolysis. Fuel 2000, 79, 1899-1906.

9. Kambara, S.; Takarada, T.; Yamamoto, Y.; Kato, K. Relation between functional forms of coal nitrogen and formation of nitrogen oxide $\left(\mathrm{NO}_{\mathrm{x}}\right)$ precursors during rapid pyrolysis. Energy Fuels 1993, 7, 1013-1020.

10. Kambara, S.; Takarada, T.; Toyoshima, M.; Kato, K. Relation between functional forms of coal nitrogen and NOx emissions from pulverized coal combustion. Fuel 1995, 74, 1247-1253.

11. Kidena, K.; Hirose, Y.; Aibara, T.; Murata, S.; Nomura, M. Analysis of nitrogen-containing species during pyrolysis of coal at two different heating rates. Energy Fuels 2000, 14, 184-189.

12. Solomon, P.R.; Colket, M.B. Evolution of fuel nitrogen in coal devolatilization. Fuel 1978, 57, 749-755.

13. Yuan, S.; Zhou, Z.; Li, J.; Chen, X.; Wang, F. HCN and $\mathrm{NH}_{3}$ released from biomass and soybean cake under rapid pyrolysis. Energy Fuels 2010, 24, 6166-6171.

14. Tian, F.J.; Yu, J.L.; McKenzie, L.J.; Hayashi, J.I.; Li, C.Z. Conversion of Fuel-N into HCN and $\mathrm{NH}_{3}$ during the pyrolysis and gasification in steam: A comparative study of coal and biomass. Energy Fuels 2007, 21, 517-521.

15. Dong, L.; Gao, S.; Song, W.; Xu, G. Experimental study of NO reduction over biomass char. Fuel Process. Technol. 2007, 88, 707-715.

16. Becidan, M.; Skreiberg, Ø.; Hustad, J.E. $\mathrm{NO}_{\mathrm{x}}$ and $\mathrm{N}_{2} \mathrm{O}$ precursors $\left(\mathrm{NH}_{3}\right.$ and $\left.\mathrm{HCN}\right)$ in pyrolysis of biomass residues. Energy Fuels 2007, 21, 1173-1180.

17. Bassilakis, R.; Carangelo, R.; Wojtowicz, M. TG-FTIR analysis of biomass pyrolysis. Fuel 2001, 80, 1765-1786.

18. Tian, F.J.; Yu, J.Y.; Mckenzie, L.J.; J Hayashi, J.I.; Chiba, T.; Li, C.Z. Formation of $\mathrm{NO}_{\mathrm{x}}$ precursors during the pyrolysis of coal and biomass. Part VII. Pyrolysis and gasification of cane trash with steam. Fuel 2005, 84, 371-376.

19. Karayildirim, T.; Yanik, J.; Yuksel, M.; Bockhorn, H. Characterisation of products from pyrolysis of waste sludges. Fuel 2006, 85, 1498-1508.

20. Tian, F.J.; Li, B.Q.; Chen, Y.; Li, C.Z. Formation of $\mathrm{NO}_{\mathrm{x}}$ precursors during the pyrolysis of coal and biomass. Part V. Pyrolysis of a sewage sludge. Fuel 2002, 81, 2203-2208.

21. Ståhlberg, P.; Lappi, M.; Kurkela, E.; Simell, P.; Oesch, P.; Nieminen, M. Sampling of Contaminants from Product Gases of Biomass Gasifiers; Technical Research Centre of Finland; Espoo, Finland, 1998.

22. Hämäläinen, J.P.; Aho, M.J.; Tummavuori, J.L. Formation of nitrogen oxides from fuel-N through $\mathrm{HCN}$ and $\mathrm{NH}_{3}$ : A model-compound study. Fuel 1994, 73, 1894-1898.

23. Werther, J.; Ogada, T. Sewage sludge combustion. Prog. Energy Combust. Sci. 1999, 25, 55-116.

24. Yang, Y.B.; Phan, A.N.; Ryu, C.; Sharifi, V.; Swithenbank, J. Mathematical modelling of slow pyrolysis of segregated solid wastes in a packed-bed pyrolyser. Fuel 2007, 86, 169-180. 
25. Glarborg, P.; Jensen, A.D.; Johnsson, J.E. Fuel nitrogen conversion in solid fuel fired systems. Prog. Energy Combust. Sci. 2003, 29, 89-113.

26. Samuelsson, J.I. Conversion of Nitrogen in a Fixed Burning Biofuel Bed. Thesis for the degree of licentiate of engineering, Chalmers University of Technology, Göteborg, Sweden, 2006.

27. Basiuk, V.A.; Douda, J. Pyrolysis of poly-glycine and poly-1-alanine: Analysis of less-volatile products by gas chromatography/Fourier transform infrared spectroscopy/mass spectrometry. J. Anal. Appl. Pyrolysis 2000, 55, 235-246.

28. Basiuk, V.A.; Douda, J. Analysis of less-volatile products of poly-l-valine pyrolysis by gas chromatography/Fourier transform infrared spectroscopy/mass spectrometry. J. Anal. Appl. Pyrolysis 2001, 60, 27-40.

29. Pels, J.; Kapteijn, F.; Moulijn, J.; Zhu, Q.; Thomas, K. Evolution of nitrogen functionalities in carbonaceous materials during pyrolysis. Carbon 1995, 33, 1641-1653.

30. Karaosmanoğlu, F.; Işığıür-Ergüdenler, A.; Sever, A. Biochar from the straw-stalk of rapeseed plant. Energy Fuels 2000, 14, 336-339.

31. Domínguez, A.; Menéndez, J.; Inguanzo, M.; Pis, J. Production of bio-fuels by high temperature pyrolysis of sewage sludge using conventional and microwave heating. Bioresour. Technol. 2006, 97, 1185-1193.

32. Barth, A. Infrared spectroscopy of proteins. Biochim. Biophys. Acta (BBA) Bioenerg. 2007, 1767, 1073-1101.

33. Ren, Q.Q.; Zhao, C.S.; Liang, C.; Shen, J.Z. Experimental research on formation behavior of fuel-nitrogen during wheat straw pyrolysis. Proc. CSEE 2008, 28, 99-104.

34. Chen, H.; Namioka, T.; Yoshikawa, K. Characteristics of tar, NOx precursors and their absorption performance with different scrubbing solvents during the pyrolysis of sewage sludge. Appl. Energy 2011, 88, 5032-5041.

35. Dong, L.; Gao, S.; Song, W.; Li, J.; Xu, G. NO reduction in decoupling combustion of biomass and biomass-coal blend. Energy Fuels 2008, 23, 224-228.

36. Zhao, J.; Grace, J.R.; Lim, C.J.; Brereton, C.M.H.; Legros, R. Influence of operating parameters on $\mathrm{NO}_{\mathrm{x}}$ emissions from a circulating fluidized bed combustor. Fuel 1994, 73, 1650-1657.

37. Yu, Q.; Brage, C.; Chen, G.; Sjöström, K. The fate of fuel-nitrogen during gasification of biomass in a pressurised fluidised bed gasifier. Fuel 2007, 86, 611-618.

38. Ledesma, E.B.; Li, C.Z.; Nelson, P.F.; Mackie, J.C. Release of $\mathrm{HCN}, \mathrm{NH}_{3}$, and $\mathrm{HNCO}$ from the thermal gas-phase cracking of coal pyrolysis tars. Energy Fuels 1998, 12, 536-541.

39. Leppälahti, J.; Koljonen, T., Nitrogen evolution from coal, peat and wood during gasification: Literature review. Fuel Proc. Technol. 1995, 43, 1-45.

40. Hansson, K.M.; Samuelsson, J.; Tullin, C.; Åmand, L.E. Formation of HNCO, HCN, and $\mathrm{NH}_{\mathrm{x}}$ from the pyrolysis of bark and nitrogen-containing model compounds. Combust. Flame 2004, 137, $265-277$.

(C) 2012 by the authors; licensee MDPI, Basel, Switzerland. This article is an open access article distributed under the terms and conditions of the Creative Commons Attribution license (http://creativecommons.org/licenses/by/3.0/). 